\title{
PERENCANAAN ASUHAN KEPERAWATAN DI DALAM KOMUNITAS
}

\author{
Sri Raudatul Jannah \\ Raudatuljannahsri@gmail.com
}

\section{Latar Belakang}

Perencanaan asuhan keperawatan bersifat individualistik dan responsif terhadap kebutuhan unik pasien. Tujuannya adalah menyusun strategi untuk mengatasi hambatan atau masalah pasien. Perawat secara teratur meninjau kemajuan pasien dan merevisi rencana perawatan yang sesuai kebutuhan pasien (Choi \& De Gagne, 2016).

Keperawatan komunitas adalah pelayanan keperawatan profesional yang ditujukan pada masyarakat dengan penekanan kelompok risiko tinggi dalam upaya pencapaian derajat kesehatan yang optimal melalui peningkatan kesehatan, pencegahan penyakit, pemeliharaan rehabilitas dengan menjamin keterjangkauan pelayanan kesehatan yang dibutuhkan dan melibatkan klien sebagai mitra dalam perencanaan, pelaksanaan, dan evaluasi pelayanan keperawatan.

Asuhan keperawatan komunitas dilakukan dengan pendekatan proses keperawatan. Penerapan dari proses keperawatan bervariasi pada setiap situasi, tetapi prosesnya memiliki kesamaan. Elemennya menggunakan metode pendekatan proses keperawatan. Proses keperawatan adalah suatu kerangka operasional dalam pelaksanaan asuhan keperawatan yang berupa rangkaian kegiatan secara sistematis sehingga masyarakat mampu secara mandiri dalam menghadapi masalah kesehatannya.

Rencana dalam tindakan keperawatan ditulis dalam suatu bentuk yang bervariasi untuk mempromasikan Perawatan yang meliputi perawatan individu, keluarga, dan komunitas. Perencanaan asuhan keperawatan pada klien ( komnunitas) seyopyanya menyertakan tiga prinsip, yaitu : pemberdayaan (empowerment), negosiasi (negotiatian), dan kerja sama lintas sektar (networking).

Tahap implementasi yang dilakukan dengan adanya rencana tindakan yang disusun dan ditujukan pada rencana strategi untuk membantu komunitas mencapai tujuan yang diharapkan. Kemudian rencana dari tindakan yang spesifik dilaksanakan untuk mengubah 
atau mengatur ulang faktor yang mempengaruhi masalah kesehatan komunitas. Tujuan dari implementasi adalah membantu komunitas dalam mencapai tujuan yang telah ditetapkan, yang mencakup peningkalan kesehatan, pencegahan penyakit, pemulihan kesehatan, dan memfasilitasi koping. Perencanan tindakan keperawatan akan dapat dilaksanakan dengan baik, jika komunitas mempunyai keinginan untuk berpartisipasi dalan implementasi tindakan keperawatan.

\section{Metode}

Metode yang digunakan pada penelitian ini adalah metode kualitatif yaitu penelitian yang digunakan untuk meneliti pada kondisi objek alamiah, dimana peneliti merupakan instrumen kunci (Sugiyono, 2005). Serta dengan menggunakan analisa dari berbagai referensi seperti buku atau jurnal dan berfokus pada metode pembelajaran mengenai perencanaan keperawatan. Referensi adalah sesuatu yang dipakai dalam pemerian informasi untuk memperkuat pernyataan dengan tegas, atau sering disebut juga dengan "rujukan". Sumber materi referensi ialah tempat materi itu ditemukan.

\section{Hasil}

Hasil ini meliputi bagaimana perencanaan dalam keperawatan. Dari hasil ini kita dapat mengetahui perencanaan asuhan keperawatan di dalam komunitas adapun langkah-langkah dalam perencanaan yang perlu diperhatikan adalah sebagai berikut:

\section{Menentukan Prioritas}

Melalui pengkajian, perawat akan mampu mengidentifkasi respons komunitas yang aktual atau potensial yang memerlukan suatu tindakan. Dalam menentukan perencanaan perlu disusun suatu sistem untuk imenentukan diagnosis yang akan diarmbil indakan perlama kali. Dalam menentukan suatu keputusanyang akan diambil untuk mengetahui tindakan yang akan kita lakukan yang lebih akurat.

\section{Menentukan Kriteria Hasil}


Penentuan kriteria hasil harus ditujukan unluk komunitas. Kriteria hasil harus menunjukkan tindakan apa yang akan dilakukan komunitas serta kapan dan sejauh mana tindakan akan bisa dilaksanakan untuk mendapatkan hasil yang spesifik serta pencapaian dalam penentuan hasil yang akan di dapat.

\section{Menentukan Rencana Tindakan}

Rencana tindakan adalah desain spesifik tentang komunitas dalam pencapaian hasil yang akan didapatkan untuk mengetahui apakah tindakan yang dilakukan telah sesuai dengan keperawatan komunitas. Serta dengan adanya rencana tindakan ini dapat membatasi beberapa faktor-foktor pendukung yang telah mencapai suatu rencana aktivitas.

\section{Dokumentasi}

Rencana dalam tindakan keperawatan ditulis dalam suatu bentuk yang bervariasi untuk mempromasikan Perawatan yang meliputi perawatan individu, keluarga, dan komunitas. Perencanaan asuhan keperawatan pada klien ( komnunitas) dan menyertakan tiga prinsip, yaitu : pemberdayaan (empowerment), negosiasi (negotiatian), dan kerja sama lintas sektar (networking).

\section{Pembahasan}

Pelayanan keperawatan profesional pada dasarnya memberi penekanan pada kualitas dan akuntabilitas dari pelayanan keperawatan yang diberikan kepada masyarakat (Potter \& Perry, 2005, p.114) bagian integral dari pelayanan kesehatan, yang ikut berperan dalam upaya penyembuhan penyakit dan pemulihan kesehatan, yang dilaksanakan pada berbagai sarana pelayanan kesehatan, baik di rumah sakit maupun di komunitas. Perencanaan adalah bagian dari fase pengorganisasian dalam proses keperawatan yang meliputi, tujuan perawatan, penetapan pemecahan masalah, dan menentukan tujuan perencanaan untuk mengatasi masalah pasien (Aziz, 2002).

Perencanaan keperawatan merupakan tahap pada proses dalam keperawatan yang dilakukan setelah penegakan diagnosa Keperawatan Perencanaan keperawatan adalah suatu rangkaian kegiatan penentuan langkah-langkah pemecahan masalah dan prioritasnya, perumusan tujuan, rencana tindakan dan penilaian asuhan keperawatan pada pasien/klien berdasarkan analisis data dan diagnosa keperawatan. Yang dilakukan berdasarkan tahapan 
yang sesuai dengan faktor beserta langkah-langkah antara suatu perencanaan dari keperawatan yang berdasarkan dengan diagnosa yang ada. Asuhan keperawatan adalah suatu pendekatan untuk pemecahan masalah pada pasien dengan memberikan pelayanan keperawatan.

Proses keperawatan adalah suatu kerangka dalam pelaksanaan asuhan keperawatan yang berupa rangkaian kegiatan secara sistematis sehingga masyarakat mampu secara mandiri dalam menghadapi masalah kesehatannya. Adanya kesungguhan, kesesuain, bersiklus, berfokus pada klien, interaktif dan berorientasi pada komunitas, adalah elemenelemen penting dalam asuhan keperawatan komunitas. Dalam melaksanakan keperawatan kesehatan masyarakat, seorang perawat kesehatan komunitas harus mampu memberi perhatian terhadap elemen-elemen yang telah ditetapkan serta melakukan pada rangkaian kegiatan dalam proses keperawatan yang berjalan secara berkesinambungan serta dinamis dalam suatu siklus melalui tahap pengkajian, analisis data, diagnosa keperawatan, perencanaan, pelaksanaan dan evaluasi.

Diagnosa keperawatan di tetapkan berdasarkan analisis dan interprestasi data yang di peroleh dari pengkajian klien. Diagnosa keperawatan memberikan gambaran tentang kesehatan yang nyata (aktual) dan kemungkinan akan terjadi, dimana pengambilan keputusannya dapat di lakukan dalam batas wewenang perawat.

Evaluasi adalah tindakan intelektual untuk melengkapi proses keperawatan yang menandakan seberapajauh diagnosis keperawatan, rencana tindakan, dan implementasinya sudah berhasil dicapai. Evaluasi memungkinkan perawat untuk memonitor keadaan yang terjadi selama tabap pengkajian, analisis, perencanaan, dan implementasi tindakan (Ignatavicius dan Bayne, 1994). Tujuan evaluasi adalah melihat kemampuan klien dalam mencapai tujuan. Hal ini bisadilaksanakan dengan mengadakan hubungan dengan klien berdasarkan respons klien terhadap tindakan keperawatan yang diberikan, sehingga perawat dapat mengambil keputusan. Serta dapat mengukur proses yang telah terjadi dalam melakukan tindakan keperawatan dalam komunitas yang dapat pencapai tujuan yang telah diharapkan dari proses tersebut. Dan bagaimana gejala yang muncul dari suatu tindakan keperawatan agar dapat mengambil data yang telah dikumpulkan dari tindakan tersebut.

Menurut WHO (1974) komunitas sebagai suatu kelompok sosial yang ditentukan oleh batas-batas wilayah, nilai-nilai keyakinan dan minat yang sama, serta ada rasa saling mengenal dan interaksi antara anggota masyarakat yang satu dan yang lainnya. 
Keperawatan komunitas salah satunya menekankan pada aspek lingkungan/komunitas sebagai faktor yang mempengaruhi masalah kesehatan. Dengan kemampuan menganalisa karakteristik lingkungan/komunitas yang menjadi area binaan yang berpotensi ataupun berisiko meningkatkan kesehatan pasien yang dapat dilakukan dalam penerapan perencanaan dalam asuhan keperawatan di dalam suatu komunitas yang dilakukan.

Keperawatan kesehatan komunitas berorientasi pada proses pemecahan masalah yang dikenal dengan proses keperawatan (nursing proses), yaitu suatu metode ilmiah dalam keperawatan yang dapat dipertanggung jawabkan sebagai cara terbaik dalam memberikan tindakan pelayanan keperawatan yang sesuai respons manusia dalam menghadapi masalah kesehatan. Langkah-langkah dalam proses keperawatan kesehatan komunitas adalah pengkajian, diagnosis, perencanaan, pelaksanaan, dan evaluasi. Dalam penerapan proses keperawatan, terjadi proses pengalih peran dari tenaga keperawatan kepada klien secara bertahap dan berkelanjutan untuk mencapai kemandirian sasaran dalam menyelesaikan masalah kesehatannya (Depkes RI,2006).

Proses keperawatan komunitas merupakan metode asuhan keperawatan yang bersifat alamiah, sistematis, dinamis, kontinyu, dan berkesinambungan dalam rangka memecahkan masalah kesehatan klien, keluarga, kelompok serta masyarakat melalui langkah-langkah seperti pengkajian, perencanaan, implementasi, dan evaluasi keperawatan (Wahyudi. 2010). Praktik keperawatan komunitas merupakan suatu teori dalam keperawatan yang memiliki beberapa pelayanan dalam melakukan tindakan promosi yaitu pada individu, keluarga dan kelompok yang terpengaruh terhadap kesehatan komunitas.

Fungsi dari keperawatan komunitas adalah memberikan pedoman dan bimbingan yang sistematis dan ilmiah bagi kesehatan masyarakat dan keperawatan dalam memecahkan masalah klien melalui asuhan keperawatan. Agar masyarakat mendapatkan pelayanan yang optimal sesuai dengan kebutuhannya di bidang kesehatan. Memberikan asuhan keperawatan melalui pendekatan pemecahan masalah, komunikasi yang efektif dan efisien serta melibatkan peran serta masyarakat. Agar masyarakat bebas mengemukakan pendapat berkaitan dengan permasalahan atau kebutuhannya sehingga mendapatkan penanganan dan pelayanan.

Sasaran dari perawatan kesehatan komunitas adalah individu, keluarga, dan kelompok khusus. Individu yaitu anggota keluarga yang memiliki suatu kesatuan utuh melalui aspek biologi, psikologi, social dan spriritual yang terdapat di dalam diri suatu individu serta dapat 
mencapai target dari sasaran komunitas. Keluarga yaitu sekelompok individu yang berhubungan erat dan menjalin interaksi yang erat antara satu sama lain di dalam lingkungannya sendiri maupun didalam masyarakat. Kelompok khusus yaitu kumpulan individu yang memiliki kesamaan jenis kelamin, umur maupun permasalahan yang sedang dialami dan dapat mendapatkan perawatan kesehatan secara komunitas yang dapat dilakukan dengan baik.

\section{Penutup}

Dari hasil dan pembahasan yang telah diuraikan diatas bahwa peningkatan perencanaan asuhan keperawatan di dalam komunitas sistem pelayanan memberikan asuhan keperawatan komunitas yang lebih maju maka diperlukan dukungan perawat, pihak rumah sakit, dan pemerintah untuk dapat mengoptimalkan pelayanan kesehatan serta dalam lingkungan masyarakat. Menurut WHO (1974) komunitas sebagai suatu kelompok sosial yang ditentukan oleh batas-batas wilayah, nilai-nilai keyakinan dan minat yang sama, serta ada rasa saling mengenal dan interaksi antara anggota masyarakat yang satu dan yang lainnya. Keperawatan komunitas adalah pelayanan keperawatan profesional yang ditujukan pada masyarakat dengan penekanan kelompok risiko tinggi dalam upaya pencapaian derajat kesehatan yang optimal melalui peningkatan kesehatan, pencegahan penyakit, pemeliharaan rehabilitas dengan menjamin keterjangkauan pelayanan kesehatan yang dibutuhkan dan melibatkan klien sebagai mitra dalam perencanaan, pelaksanaan, dan evaluasi pelayanan keperawatan.

\section{Daftar Pustaka}

Akbar, M. A. (2019). BUKU AJAR KONSEP-KONSEP DASAR DALAM KEPERAWATAN KOMUNITAS. CV Budi Utama.

Amin, M. H. L. (2019). Sistem Pelayanan Asuhan Keperawatan Kesehatan Komunitas: Studi Kasus di Dusun Mensaleng. Jurnal Kesehatan Qamarul Huda, 7(2), 59-70.

Andarmoyo, S. (2012). Keperawatan Keluarga: Konsep Teori, Proses, dan Praktik Keperawatan.Yogyakarta: Graha Ilmu. 
Andini, Nur A. (2018). Gambaran Faktor Yang MempengaruhiPelaksanaan Asuhan Keperawatan Komunitas di Puskesmas Kota Makassar. Jurnal FIK,10-28.

Butar-Butar, J., \& Simamora, R. H. (2016). Hubungan Mutu Pelayanan Keperawatan dengan Tingkat Kepuasan Pasien Rawat Inap di RSUD Pandan Kabupaten Tapanuli Tengah. Jurnal Ners Indonesia, 6(1), 50-63.

Christina, P., Agustin. I., \& Aat. Y. (2019). Analisis Keridaksinambungan Dokumentasi Perencanaan Asuhan Keperawatan : Metode Ishikawa. Jurnal Ilmiah Kesehatan (JIK), XII(II), 518-524.

Dewi, N. S., Artika. N., \& Panji. W. W. (2019). Pengembangan Desain Perencanaan Sistem Informasi Geografis Sebagai Alternatif Pembelajaran Dalam Keperawatan Kesehatan Komunitas. Journal of Holistic Nursing and Health Science, 2(1), 22-30.

Efendi, F., \& Makhfudli. (2009). Keperawatan Kesehatan Komunitas : Teori dan Praktikdalam Keperawatan. Jakarta : Salemba Medika.

Harnilawati. (2013). Pengantar Ilmu Keperawatan Komunitas. Sulawesi: Pustaka As Salam.

Mandayani, R., \& Teuku S. A. (2016). PERSEPSI MASYARAKAT TENTANG PRAKTIK KEPERAWATAN DI ULEE KARENG KOTA BANDA ACEH. Jurnal Ilmiah Mahasiswa Fakultas Keperawatan, 1(1), 1-9.

Simamora, R. H. (2005). Hubungan Persepsi Perawat Pelaksana Terhadap Penerapan Fungsi Pengorganisasian Yang Dilakukan Oleh Kepala Ruangan Dengan Kinerjanya Diruang Rawat Inap RSUD Koja Jakarta Utara (Doctoral dissertation, Tesis FIK UI, Tidak dipublikasikan).

Swarjana, I Ketut. (2016). Keperawatan Kesehatan Komunitas. Yogyakarta : ANDI. 